\title{
Examination of Determinants of Project Performance in Construction Companies in Mogadishu
}

\author{
Ali Yassin Sheikh Ali* \\ Faculty of Economics, SIMAD University \\ Mohamed Saney Dalmar \\ Ministry of Finance, Federal Government of Somalia \\ Ali Abdulkadir Ali \\ Faculty of Humanities, University of Somalia
}

\begin{abstract}
The main aim of the current study was to examine determinants of project performance in construction industry. The sample size of this study was 200 employees from construction companies in Mogadishu. Data was collected through semi structured questionnaire, and the data was analyzed by using SPSS. Different statistical techniques were performed to test the research objectives of this study Therefore, the Researchers found that all factors had significant positive relationship with project performance. The project managers should be aware of all factors that can threaten the successful implementation of the project. They will ensure that adequate performance reporting is carried out at all stages. This ensures that problems can be identified quickly and measures taken to mitigate them.
\end{abstract}

Keywords: Project performance, construction companies, Mogadishu

DOI: $10.7176 / \mathrm{EJBM} / 11-6-04$

\section{INTRODUCTION}

Somalia, as an emerging economy, is faced with a countless of project management challenges both technical and managerial sides. First, there is a shortage of empirical studies on the success of project management in Somalia, thus leaving no documentation on the best practices in that field. Secondly, whereas projects in general have their challenges regarding implementation and consequently success, development projects in particular are plagued by a unique set of problems and challenges. The PMBOK ${ }^{\circledR}$ Guide definition of project management is "application of knowledge, skills, tools, and techniques to project activities to meet the project requirements. In Somalia projects can have a successful implementation by getting the following products: sound financial support, effective communication, high monitoring and evaluation and good planning(Marren, 2016)

For instance, the nature of project funding in Somalia poses a significant challenge for government as well as non-governmental agencies. The funding provided by donors for development projects is so extensive that they are now referred to as development partners, a reflection of how dependent Ghana's development is on donor support. On the other hand; every project management must meet these success factors: planning, controlling, monitoring, quality management, communication and information, risk management, procurement management, and human resource management and effectively managing the project constraints and many other factors. But, achieving these factors would lead the project to be success. Davis found in her paper some of the common success factors in projects like: project cost and budget, communication and cooperation, stakeholder satisfaction, competent project manager and clear project time bound and objectives(Davis, 2014).

Despite of that, with the absence of those factors could also lead the project to be in trouble and these challenges the project management which will have an impact on the overall quality and success of projects in Somalia.

Due to the innumerable challenges facing project managers in Somalia, the purpose of the study is to identify and assess the quality of project management practices by determining and ranking the factors that affect project success. Knowledge of the best practices would improve the quality of project management and consequently project success. Construction industry sector is every nation's economic development backbone and they are a mix of very complex processes that seldom go according to the planned schedule. Project implementation is the stage where all the planned activities are put in to action, the project is produced and the performance capabilities are verified. A project is generally considered to be performing well if it finishes on planned timeframe, comes in on planned budget, and reaches all the goal and objectives originally set for it and is accepted and used by the project stakeholders (Sambasivan \& Soon, 2007)

In a global study on construction project poor performance is global phenomenon, where 9 of 10 projects faced the overrun in the range of 50 to 100\%. (Flyvbjerg, Skmaris Holm, \& Buhl, 2003)In Saudi Arabia, Assaf and Al-Hejji identified that only $30 \%$ of construction projects were finished within the planned completion dates and that the average time overrun was between $10 \%$ and 30\%.(Assaf \& Al-Hejji, 2006)Construction industry in 
developed countries is also affected by poor construction project performance where nearly one third of the client's complaint that their projects generally overran the allocated budget (Sambasivan \& Soon, 2007).

For every construction project a number of deficiencies occur, and continue to occur. Occasionally, new problems develop and despite efforts to implement success factors, these problems have persisted. While a body of research exists that identifies a range of success factors, no research was found to exist in success factors of construction projects in Mogadishu. This gap in the research has motivated the current study. Construction projects are unique and are perceived to be inherently risky due to the participation of multiple parties, diverse in nature and have the potential to lead to undesirable consequences. Many disputes happened among house owners, clients, and parties involved in construction (especially contractors). Usually, quality is one of the constraints in project success and most of the time because of poor workmanship during construction period many issues aroused (Ali \& Wen, 2011). In the context of project life cycle and project triple constraints, many factors bring project delays (Mydin, Sani, Salim, \& Alias, 2014).

A building project is completed through a combination of many events and interactions, planned or unplanned, over the life of a facility, with changing participants and processes in a constantly changing environment. Certain factors are more critical to a project's success than others. These factors are called critical project success factors. The term Critical Success Factors in the context of the management of projects was first used by Rockart in 1932 and is defined as those factors predicting success of projects (Salleh, 2009).

Success is defined as "results much better than expected or normally observed in terms of cost, schedule, quality, safety and participant satisfaction". The investigation of the success factors of construction projects has attracted the interest of many researchers and many studies have been conducted, with the aim of providing contract parties with valuable insight into how to consistently achieve superior results for their projects. Although construction projects are by their nature repetitive activities, each one has its own characteristics and circumstances (Salleh, 2009).This research focuses on building construction projects in Mogadishu allowing the ranking of success factors for these construction projects. This study will contribute to the body of knowledge on project management best practices and critical success factors, within a developing country particularly Somalia context. This study aims to contribute in the identification of the important factors of a project success in Somalia.

\section{LITERATURE REVIEW}

Atkinson (1999) historically, studied on project success started in the mid-1900s and its attributes are being equated to cost, time and quality. For over 50 years, project success has been linked to the achievement of the "Iron Triangle" of cost, time and quality. Morris (2001) the traditional view for project success is to deliver projects on time, in budget and to scope, or to achieve the narrow view of the "so-called golden triangle". Belassi (1996) noted that early project management literature advocates that project success will be realized when the project achieves the three major objectives of completion on time, within budget and to quality or performance specifications. These authors agree that most of the early studies associate project success with time, cost and quality and if these are not met, the project is considered a failure.

Barakat studied success factors for local development project management case of Taroudant province morocco. The purpose of this paper is to explore from different perspectives of the local players looking at the key success factors that can contribute to the local development project management success. Results indicated that all factors are found to be vital in achieving the project management success. It was also revealed that the relative importance of these factors varies significantly at different phases of project lifecycle. Barakat et al., (2015). According to Damiebi investigated the critical success factors required for successful deepwater development in offshore Nigeria. The findings indicated that the project size and project type influences most of the CSFs.(Dennifiberesima, Shima, \& Rani, 2011).

According to Alias, Zawawi, and Yusof, (2014)explored their study of Determining Critical Success Factors of Project Management Practice. The main purpose of the study was to identify the extent of the relationship between Critical Success Factors and the project performance. Researchers of the study employed questionnaire as the instrument of the data collection. The research findings will be expected to assist the organization in evaluating the performance of project management. Results from this study are also expected to help project management practitioners to achieve specific construction performance level. Then it will define the critical factors that lead to project success and provide a forecasting tool to enable parties to rapidly assess the possibility of a successful project from their viewpoint. Finally, the conceptual framework was developed by identifying five variables for project success namely project management action, project procedures, human factors, external issues and project related factors. The researchers of this study pointed out that a further study can undertake some areas that are related to the current topic.

Berssaneti and Carvalho(2015) were made identification of variables that influence project success in Brazilian companies. The purpose of the study was to analyze the relationship between the project success and the project management growth. Survey questionnaire was employed as methodology and a sample size of 336 Brazilian companies. The findings of the study reveals that project management maturity have significant 
relationships with the all triangle dimensions of project success like cost, time and the technical performance. Project manager and the project management support were the moderating variables which have significant effect on the time success aspect. Finally, the study recommends that further study can be undertaken in to the efficiency dimensions.

Paulo et al(2014) investigated the critical success factors in project management. The purpose of the paper was to understand the relationship amongst the critical success factors in project management and the project outcome. The study was based on document analysis and survey research with questionnaire and a sample size of 133. The results of the study indicates that the management support and clearly defined and detailed scope are the major factors that have the most significant impact on the project management success. The paper provides ultimately these suggestion for further research like increasing the number of companies under the study, prioritize and analyze each project lifecycle's phase and study the maturity level of the companies in a detailed way.

According to Saleh and Freidi(2014) examined the determinants of the Best Practices for Successful Project Management. The aim of the study was to identify the determinants that are most familiar in project success. The findings of the paper was obtained from different client organization, contractors and project managers as they are what determines the project success. Interestingly, the highly rated determinants that determine the project management success were project planning, communication and monitoring, project risk management, project policy and technical management and the project sustainability. The researcher suggested that to study not only the determinants of the project success but for further study focus can be to investigate the relationship amongst the independent variables of the study.

Ofori examined project management practices and critical success factors-a developing country perspective. The study applied an exploratory approach and utilized a survey method to collect data on project management practices of Ghanaian organizations. Purposive sampling was used in selecting the sample which comprised 200 managers from different economic sectors. Findings from the study revealed that the critical factors that contribute to the success of a project include top management support, effective communication, clarity of project purpose and goals, and stakeholder involvement Ofori(2013).

According to Pakseresht(2012)explored the determinants of critical success factors in construction projects. The aim of the study was to identify and develop a rank that indicates critical success factors in construction projects. The researcher employed questionnaire as a main tool of data collection with the sample of fifty eight people of staff managers at different organization and also the data in this study were analyzed statistical package which is called SPSS V.16.

The findings of the study revealed that the project success has different priorities and importance, here are the bases of their importance to the project success: project strategic plan, executive experience, and economic and technical assessment of the required resources.

Another study examined the critical success factors influencing performance of construction projects. The study has the purpose to investigate the critical factors that lead to project construction succeed. The analysis of the study outlines that factors such as the external environment, the project manager's performance and the other factors that are related to organizational context are the major factors that can determine the construction project's success.(Babu, 2015). Also, Tsiga, Emes, \& Smith studied the critical success factors for projects in the construction industry in London.

They identified 58 success factors in their study. Data was collected through questionnaire and forty nine responses were collected from project managers whom are having more than 15 years of experience in the field. To rank the categories they adopted the relative importance index. From the findings, the project organization, project manager competence, project risk management, project team competence and requirements management were the most important rated. (Tsiga, Emes, \& Smith, 2016).

\section{METHODOLOGY}

The current study establish causal relationship between variables so researchers attempted explanatory research design to emphasis on studying a situation or a problem in order to explain the relationships between determinants of project success. A cross-sectional survey research design was adopted for the purpose of this study because the Cross-sectional is cost and time effective because data can be gathered just once perhaps over a period of days or weeks or months, in order to answer research questions (Sekarana, 2003).

The target populations of this study were construction companies who implemented construction projects in Mogadishu, Somalia. The sample size of this study was the construction companies in Mogadishu, there are no comprehensive directory of number of employees in these companies in Somalia, the researchers team took 200 employees from different department as a sample frame for this study. The study were used both probability and non probability sampling techniques to create a sampling frame. In probability sampling use stratified sampling to ensure that different departments of construction companies were included in the survey. Once strata are identified then use non probability sampling to carry out the real study.

The researchers used purposive sampling techniques of non-probability sampling because the researchers 
cannot obtain the list of employee names from the construction firms. Therefore, data was collect from those employees who were conveniently available enough knowledge to the indicators under investigation and willing to co-operate. The primary data of this study will be collected through questionnaire. Questionnaire is used in view of the reality that the study is concerned with variables that cannot be observing such information is best way of collecting data through questionnaire (Saunders et al, 2009).

\section{FINDINGS AND DISCUSSIONS}

\section{1: Normality distribution test}

Normality test is important when conducting a research as it can affect the results and make bias conclusion. Before conducting further analysis for the main variables in the study such as examination of factors affecting and project performance, the research conducted a normality test for multivariate items. Several techniques were employed for testing the normality including sample histogram, scatter plot Skewness and kurtosis. Table1 provides the normality test for main variables in this study by using skewness and kurtosis. Therefore with the large sample size the data is more likely normally distribution. By looking the frequencies, the score for skewness and kurtosis.

Table 1: Data Normality test

\begin{tabular}{|l|r|r|r|r|r|r|r|r|r|}
\hline $\begin{array}{l}\text { Normality } \\
\text { test }\end{array}$ & Cost & Time. & Quality & Productivity & People & $\begin{array}{c}\text { Health } \\
\text { and } \\
\text { Safety }\end{array}$ & $\begin{array}{c}\text { Innovation } \\
\text { and } \\
\text { Learning }\end{array}$ & Environment & $\begin{array}{c}\text { Project } \\
\text { success }\end{array}$ \\
\hline Mean & 3.4400 & 3.4911 & 3.5358 & 3.4480 & 3.6250 & 3.4162 & 3.6600 & 3.5600 & 3.4347 \\
\hline $\begin{array}{l}\text { Std. } \\
\text { Deviation }\end{array}$ & .68962 & .64089 & .81374 & .76118 & .80083 & .80524 & .75900 & .88299 & .54918 \\
\hline Skewness & -.373 & -.351 & -.604 & -.609 & -.517 & -.523 & -.671 & -.492 & -.403 \\
\hline Kurtosis & -.347 & -.146 & -.286 & .055 & -.186 & -.189 & .143 & -.525 & -.060 \\
\hline $\begin{array}{l}\text { Std. Error } \\
\text { of } \\
\text { Kurtosis }\end{array}$ & .342 & .342 & .342 & .342 & .342 & .342 & .342 & .342 & .342 \\
\hline
\end{tabular}

\section{2: Reliability test}

Table 2 shows the results of reliability coefficients. All variables achieved an acceptable level of internal consistency since all scores were greater than the rule of thumb (>.70). Cost factor Cronbach ${ }^{\text {ee }}$ s alpha (0.747) Time factor (0.751) Quality factor (0.716) Productive factor (0.734) People factor (0.742) Health and Safety factor (0.707) Innovation and learning factors $(0.766)$ where as perceived Environment factors $(0.695)$. however; project performance measurements obtained highest alpha with 0.82 ; therefore; we can proceed

Table 2. Reliability test for the variables

\begin{tabular}{|l|l|c|l|}
\hline No & \multicolumn{1}{|c|}{ Variable } & Items & \multicolumn{1}{|c|}{ Cronbach's Alpha } \\
\hline 1 & Cost factor & 7 & 0.747 \\
\hline 2 & Time factor & 9 & .751 \\
\hline 3 & Quality Factor & 7 & .716 \\
\hline 4 & Productivity factor & 5 & .734 \\
\hline 5 & People factor & 4 & .742 \\
\hline 6 & Health and safety factor & 4 & .707 \\
\hline 7 & Innovation and learning factors & 5 & .766 \\
\hline 8 & Environment factors & 5 & .695 \\
\hline 9 & Project Performance & 10 & 0.82 \\
\hline
\end{tabular}

\section{3: Demographic profile}

The study collected information related to sample characteristics of demographic profile (see Table 3 ). The study collected reaction from 200 employees and managers of the Construction firms In Mogadishu-Somalia. As gender variable, $(97.5 \%)$ of the participants in the study were male while $(2.5 \%)$ were females. At the side of marital status $(64 \%)$ of the respondents were married and contributed by $(36 \%)$ were single. In terms of age factor, majority of the respondents were below 30 years old from respondents as shown in the below table $(36 \%)$ were between the age 20-30 years, followed by those aged between $31-40$ years (33\%), ages between $41-50$ years (25\%). 
Very few $(6 \%)$ were more than 51 years.

The majority of the respondents had experience between 2-3yrs whose percentages was (36.5\%) of total respondents, experience between 3-4yrs whose percentage was (29\%) of total respondents, experience between 45 yrs whose percent was $(19.5 \%)$ of the total respondents, experience between 1-2yrs whose respondents was (15\%) of the total respondents.

In terms of the level of education the majority of the respondents are bachelor degree which are $(41.5 \%)$ of total respondent, Master degree were $(30 \%)$, others ware $(15 \%)$ of total respondent and The respondents of secondary were $(13.5 \%)$.

Table 3.Demographic profile

\begin{tabular}{lrc}
\hline Gender of Responds & Frequency & Percentage \\
\hline Male & 195 & 97.5 \\
Female & 5.0 & 2.5 \\
Total & 200 & 100.0 \\
Marital Status of Responds & Frequency & Percentage \\
Single & 72 & 36 \\
Married & 128 & 64 \\
Total & 200 & 100 \\
Age of Responds & Frequency & Percentage \\
$20-30$ & 72 & 36.0 \\
$31-40$ & 66 & 33.0 \\
$41-50$ & 50 & 25.0 \\
51 above & 12 & 6.0 \\
Total & 200 & 100.0 \\
Experience of Responds & Frequency & Percentage \\
1-2 yrs & 30 & 15.0 \\
2-3 yrs & 73 & 36.5 \\
3-4 yrs & 58 & 29.0 \\
4-5 yrs & 39 & 19.5 \\
Total & 200 & 100.0 \\
Education of Responds & Frequency & Percentage \\
Secondary & 27 & 13.5 \\
Bachelor degree & 83 & 41.5 \\
Master Degree & 60 & 30.0 \\
Other & 30 & 15.0 \\
Total & 200 & 100.0 \\
\hline
\end{tabular}

\section{4: Zero-order correlation of variables}

The relationship between cost factor and project performance Investigated by using Pearson correlation the result obtained that there is strong positive relationship between variables. As shown in the table there is significant relationship between cost factors and project performance $\left(r=\mathbf{. 7 9 7}^{\text {*** }} \mathbf{p}=\mathbf{0 . 0 1}\right)$. The relationship between time factors and project performance Investigated by using Pearson correlation the result obtained that there is strong Positive relationship between variables. As shown in the table there is significant relationship between time factors and project performance $\left(\mathbf{r}=.777^{* *} \mathbf{p}=\mathbf{0 . 0 1}\right)$.

The relationship between quality factors and project performance Investigated by using Pearson correlation the result obtained that there is strong Positive relationship between variables. As shown in the table there is significant relationship between quality factors and project performance $\left(\mathbf{r}=\mathbf{5 9 9}^{* * *} \mathbf{p}=\mathbf{0 . 0 1}\right)$. The relationship between productivity factors and project performance Investigated by using Pearson correlation the result obtained that there is strong Positive relationship between variables. As shown in the table there is significant relationship between Productivity factors and project performance $\left(r=. \mathbf{. 5 8}^{* *}, \mathbf{p}=\mathbf{0 . 0 1}\right)$.

The relationship between People factors and project performance Investigated by using Pearson correlation the result obtained that there is weak Positive relationship between variables. As shown in the table there is significant relationship between People factors and project performance $\left(\mathbf{r}=\mathbf{. 4 6 2}{ }^{* *}, \mathbf{p}=\mathbf{0 . 0 1}\right)$. The relationship between health and safety factors and project performance Investigated by using Pearson correlation the result obtained that there is strong Positive relationship between variables. As shown in the table there is significant relationship between People factors and project performance $\left(\mathbf{r}=\mathbf{. 6 3 0}{ }^{* *}, \mathbf{p}=\mathbf{0 . 0 1}\right)$.

The relationship between Innovation and learning factors and project performance Investigated by using Pearson correlation the result obtained that there is strong Positive relationship between variables. As shown in the table there is significant relationship between Innovation and learning factors and project performance ( $\mathbf{r}$ $\left.=\mathbf{. 5 6 5}^{* * *}, \mathbf{p}=\mathbf{0 . 0 1}\right)$. The relationship between Environment factors and project performance Investigated by using 
Pearson correlation the result obtained that there is weak Positive relationship between variables. As shown in the table there is significant relationship between Environment factors and project performance $\left(\mathbf{r}=\mathbf{. 4 4 5}{ }^{* * *}, \mathbf{p}=\mathbf{0 . 0 1}\right)$.

Table 4: correlation between variables

\begin{tabular}{|c|c|c|c|c|c|c|c|c|c|c|c|}
\hline Variables & Mean & Std. Deviation 1 & & 2 & 3 & 4 & 5 & 6 & 7 & 8 & 9 \\
\hline Cost & 3.44 & .690 & 1 & & & & & & & & \\
\hline Time & 3.49 & .641 & $.431^{* *}$ & 1 & & & & & & & \\
\hline Quality & 3.54 & .814 & $.400^{* *}$ & $.428^{* *}$ & 1 & & & & & & \\
\hline Productivity & 3.448 & 0.761 & $.234^{* *}$ & $.267^{* *}$ & $.473^{* *}$ & 1 & & & & & \\
\hline People & 3.62 & .801 & $.280^{* *}$ & $.380^{* *}$ & $.453^{* *}$ & $.289^{* *}$ & 1 & & & & \\
\hline $\begin{array}{l}\text { Health and safety } \\
\text { Innovation }\end{array}$ & 3.41625 & 0.805 & $.317^{* *}$ & $.387^{* *}$ & $.452^{* *}$ & $.338^{* *}$ & $.409^{* *}$ & 1 & & & \\
\hline $\begin{array}{l}\text { and } \\
\text { learning }\end{array}$ & 3.66 & .759 & $.417^{* *}$ & $.467^{* *}$ & $.499^{* *}$ & $.296^{* *}$ & $.420^{* *}$ & $.407^{* *}$ & 1 & & \\
\hline Environment & 3.56 & .883 & $.307^{* *}$ & $.349^{* *}$ & $.351^{* *}$ & $.323^{* *}$ & $.396^{* *}$ & $.292^{* *}$ & $.387^{* *}$ & 1 & \\
\hline $\begin{array}{l}\text { Project } \\
\text { performance }\end{array}$ & 3.43 & .640 & $.797^{* *}$ & $.777^{* *}$ & $.599^{* *}$ & $.568^{* *}$ & $.462^{* *}$ & $.630^{* *}$ & $.565^{* *}$ & $.445^{* *}$ & 1 \\
\hline
\end{tabular}

\section{5: Hypothesis test}

The current study wanted to investigate the influence of determinants on project performance in construction industry in Somalia also examines the eight different factors effecting project performance. Eight hypotheses were developed based on literature, in order to test these hypotheses, a linear regression analysis was conducted to examine the effects of these predictors on criterion variables. The regression assumptions were checked before proceeding to further analysis. The linearity, Collinearity, and outliers were also checked. Therefore, no violations were observed.

As shown in table 5 below; all determinants had positive significance influence of project performance thus all hypotheses were supported. All the independent variables together explained $65 \%$ of the changes to the project performance.

\begin{tabular}{cccc}
\multicolumn{3}{c}{ Table 5: Model test } \\
\hline No & Variables & Beta & P Value \\
\hline $\mathbf{1}$ & Cost & .591 & 0.01 \\
$\mathbf{2}$ & Time & .431 & 0.00 \\
$\mathbf{3}$ & Quality & .214 & 0.00 \\
$\mathbf{4}$ & Productivity & 0.361 & 0.00 \\
$\mathbf{5}$ & People & .201 & 0.00 \\
$\mathbf{6}$ & Health and safety & 0.145 & 0.06 \\
$\mathbf{7}$ & Innovation and learning & .395 & 0.00 \\
$\mathbf{8}$ & Environment & .135 & 0.00 \\
& R square & .654 & \\
\hline
\end{tabular}

\section{Discussion and conclusion}

The present study shows the relationship between the examination of factors affecting the project performance. Eight hypothesis were developed based on the literature; cross sectional data was employed with purposive technique, this study collected 200 respondents from construction company's employees and managers in the in Mogadishu-Somalia. Employees and Managers provided responses to nine main constructs, namely cost factors, productivity, Time factors, Quality factors, People factors, Health and safety, Innovation and leaning factors, Environment factors and Project performance.

The results of the linear regression suggested that the criterion variable (Project Performance) had statistically significant correlation with the eight predictors namely Cost factors, Time factors, Quality factors, productivity factors, People factors, health and safety innovation and leaning factors and environment factors; therefore, all hypothesis were supported.

These findings are inline with existing literature for example Michael G. Oladokun (2012) conducted a 
research title " project performance Indicators of Design and Build Projects in Nigeria" and objectives of their studies were to determine the key performance indicators for Design-Build projects, examine the importance of these indicators on performance outcomes of Design-Build projects and ascertain the degree of agreement among the key stakeholders on the indicators and they found to reveal that eight project Performance Indicators were identified. They are cost factors, time factors, quality factors, People factors, Innovation and leaning factors and Environment factors.Other study conducted by Adnan Enshassi, Sherif Mohamed, Saleh Abushaban (2009) found similar results; the study were investigating factors affecting the Performance of construction projects In the Gaza Strip" and they found to indicate that all factors agree that the most important factors affecting project performance are: Cost factors, Time factors, Quality factors, People factors, Innovation and leaning factors and Environment factors. The most of respondents agreed that there is significantly positive relationship between Factors Affecting the Performance of Construction Projects in the Gaza Strip.

\section{Conclusion}

In today's world there is a rising frequency of conducting projects in all fields and as a result this determined the increasing importance of project management success. As other researchers from previous literature point out, the most probably essential factors of project success are quoted as being considering the constraints of cost, time and performance. But these alone are not sufficient to determine whether a project had been successful or not.

Though the existing literature indicates different points of view regarding the topic under discussion, in practice it might become even more challenging and complicated which could further lead to a vague definition of project success. Every public and business project is required to achieve its preset objectives through effective management hence success factors are strongly recommended and watched.

The research study that is presented here in this article aims to identify the success factors which determine the nature of outcome in implementing projects which then makes this study relevant and appropriate as some of the project success factors have higher influence than others. So the researchers recommend strongly that future and further study be made so as to perpetuate for larger samples and then test the association among the rankings of the prominent project success factors.

\section{References}

Alias, Z., Zawawi, E., \& Yusof, K. (2014). Determining Critical Success Factors of Project Management Practice: A conceptual framework. Procedia - Social and Behavioral Sciences, 153, 61-69. https://doi.org/10.1016/j.sbspro.2014.10.041

Atkinson, R. (1999.). Project management: cost, time and quality, two best guesses and a phenomenon, it's time to accept other success criteria. International Journal of Project Management.

Babu, S. S. (2015). Critical Success Factors Influencing Performance of Construction Projects, 3285-3292. https://doi.org/10.15680/IJIRSET.2015.0405048

Barakat, O., Bendou, A., \& Martin, J. C. (2015). Success Factors for Local Development Project Management Case of Taroudant Province - Morocco, 2015. https://doi.org/10.5171/2015.607790

Belassi, W. \&. (1996). A new framework for determining critical success/failure factors in projects. . International Journal of Project Management, , 141-152.

Berssaneti, F. T., \& Carvalho, M. M. (2015). ScienceDirect Identi fi cation of variables that impact project success in Brazilian companies. JPMA, 33(3), 638-649. https://doi.org/10.1016/j.ijproman.2014.07.002

Davis, K. (2014). Different stakeholder groups and their perceptions of project success,. International Journal of Project Management, 32, 189-201.

Denni-fiberesima, D., Shima, N., \& Rani, A. (2011). An evaluation of critical success factors in oil and gas project portfolio in Nigeria, 5(6), 2378-2395. https://doi.org/10.5897/AJBM10.1129

Marren, A. (2016). Factors Determining Project Implementation of Health Projects in Gedo Region, Somalia.

Morris, P. (2001). Updating the project management bodies of knowledge. Project Management Journal, .

Ofori, D. F. (2013). Project Management Practices and Critical Success Factors-A Developing Country Perspective. International Journal of Business and Management, 8(21), 14-32. https://doi.org/10.5539/ijbm.v8n21p14

Pakseresht, A. (2012). Determining the Critical Success Factors in Construction Projects : AHP Approach, 383393.

Paulo, B., Felix, C., Quelhas, O. L. G., Zotes, L. P., Shimoda, E., \& França, S. (2014). Critical Success Factors in Project Management: AnExploratory Study of an Energy Company in Brazil, 14(10).

Saleh, S., \& Freidi, A. (2014). Determinants of the Best Practices for Successful Project Management, 7(3), 173186.

Tsiga, Z., Emes, M., \& Smith, A. (2016). Critical Success Factors For The Construction Industry 1 Background, $V$ (Viii), 1-12. 